\title{
Human Resource Management in Healthcare
}

\author{
Jana Blštákován ${ }^{1,}$, Jana Palenčárová ${ }^{1}$ \\ ${ }^{1}$ Department of Management, Faculty of Business Management, University of Economics in \\ Bratislava, Dolnozemská cesta 1, 85235 Bratislava, Slovakia
}

\begin{abstract}
Contemporary healthcare systems face several challenges. The main management challenges include shortage and low satisfaction of health professionals. Satisfaction and motivation of medical staff is crucial for their stabilization and quality work-medical performance. The positive impact of HRM practices on increasing employee satisfaction and engagement is scientifically proven. Currently, HRM practices in healthcare are used in a limited way, often only at the level of HR or labour law and union bargaining. This is indicative of the low level of HR development. It is desirable to make full use of HRM practices in healthcare. The aim of this paper is to identify and define the challenges of human resource management in healthcare and explain the importance of implementing developed HRM practices to improve the quality of health care delivery. The research method used is a literature search. The investigation of the relationship between quality human resource management and healthcare delivery is considered important because the knowledge and competency to manage people are not necessary to hold a management position in most healthcare professions in Slovakia. In the world's best hospitals, we find developed HRM with a positive impact on employee satisfaction and medical indicators.
\end{abstract}

\section{Introduction}

Healthcare as a system is a major social, economic and political issue worldwide. According to Ozorovský and Vojtek, in many countries there is a drive to reform the health care system because for various reasons there is dissatisfaction with the level or manner of care provided [1]. As a result of the COVID pandemic, the need for health reforms continues to grow.

Several authors agree that EU health systems are increasingly interacting and have faced increasing common challenges over the last decade $[2,3,4]$.

The sector suffers from a shortage and unequal distribution of health workers. The ageing population, coupled with the rise of chronic and age-related diseases, is leading to an increasing demand for healthcare. Health systems are facing rising healthcare costs due to the continuous development of technology and increasing demands on competences. As a result of technological and medical advances, the structure of procedures is also changing, highly specialised activities are being centralised, and demands for safety, quality and 
efficiency have increased, even for less specialised interventions. Further, there are inequalities in preventive healthcare and access to healthcare [2].

The aforementioned realities are particularly challenges for the management of health care facilities. It is necessary to seek strategies for performance management and medical staff development in line with technological and demographic trends in society. We consider it important to pay attention to human resource management tools and policies for managing people in healthcare. The application of modern human resource management tools in healthcare is one of the key responses to the challenges of healthcare.

\section{Literature review}

The development of human resource management follows the development of the economy and the advent of innovation during all 4 industrial revolutions. The first HR managers and the first HR departments appeared in manufacturing companies at the turn of the 19th and 20th centuries and their work was initially limited to administration, accounting and resource planning. For the purpose of knowing the level of quality of human resource management in healthcare, we consider it necessary to describe the developmental stages and to recognize the development of personnel management. The development of human resource management can be briefly described by 4 basic developmental stages [5].

The basic level of human resource management (HRM) is the personnel department, which provides personnel administration, payroll accounting and basic labor law. In the second tier, there is a specialization of HRM into selection, training, organizational design management, and compensation. The HR function includes HR service centres that provide services to employees and HR business partners that support managers at a strategic level. The third level is a superstructure in which HRM provides integrated talent management. New roles are succession planning, talent management, leadership support, and the development of a coaching culture. The most advanced departments of HRM are fully integrated with the business, are digitized and can predict future developments and deliver value through big data analytics. They are constantly expanding their knowledge and their impact [6]. They are not focused on what they do, but on what they deliver [7]. The impact of HRM activities on the performance of the organization is measured and evaluated.

The impact of the 4.0 era on HRM through changes in the values, roles, architecture and content of HRM is described by Blstakova's model [8], which, through conceptual issues of HRM, can form the basis for setting a developed HRM strategy and subsequent substrategies.

Several global studies have confirmed the relationship between the use of modern, developed HRM systems and the organizational performance of a company [9]. Similarly, Jankelova's research [9] in 44 Slovak hospitals confirmed the positive impact of the blended role (mature role) of HRM in healthcare facilities (hospitals) on their organizational performance. For example, West et al. reported that HRM systems in healthcare facilities directly influence the quality of healthcare provided and the mortality rate of patients in hospitals [10].

West et al. list specific practices of developed HRM that previous research suggests are most important to use - sophisticated management appraisal systems, staff safety, and the level of investment in people (as expressed by effective human resource management and, in particular, investment in training and development) [10]. Similarly, Townsend et al. state that, an HRM system must use advanced techniques (such as miracle question) to understand employee problems and solve them [11]. West points out that it is not enough to use advanced HRM techniques in isolation, but it must be a group of interrelated highperformance HRM practices [10]. Townsend et al. state that the growing importance of 
HRM is a signal to employees that employees also have a strong position in the company [12]. The development of HRM strategies and tools is not homogeneous. The development of HRM is often positively influenced by the competitive environment, the form of ownership of the organization and its size. HRM develops fastest in highly competitive environments with high demand for quality labour (e.g., IT services, telecommunications sector). In sectors such as primary agricultural production, human resource management is sufficient to cover basic staffing activities in the long term.

The positive relationship between a well-developed HRM system and transformational leadership of managers in the healthcare sector, which in turn has a positive impact on employee satisfaction and loyalty, has been described in studies by several authors [9].

According to Joniaková and Jankelová, burnout and low job satisfaction are among the problems of contemporary healthcare [13]. Meanwhile, according to West et al. the satisfaction and motivation of medical staff is crucial for their stabilization (reduction of attrition to other departments, increased interest in studying and working in healthcare) and quality work performance (reduction of patient mortality, compliance with procedures and regulations, reduction of nosocomial infections, etc.). $[10,13]$. Other studies show that job satisfaction is among the key factors for health professionals worldwide [14]. The positive impact of HRM practices on increasing employee satisfaction and motivation has been scientifically proven by several authors $[10,13,15,16]$. It is desirable to make full use of the current knowledge on human resource management in healthcare.

\section{Methodology}

The aim of this paper is to identify and define the challenges of human resource management in healthcare and to explain the importance of implementing well-developed human resource management practices to improve the quality of healthcare delivery. The research method is a literature search. The article is the result of analysis of published studies, analogy and comparison of relevant findings. The result is a synthesis and enrichment of the current knowledge about human resource management in healthcare in Slovakia. The article presents the author's personal experience with human resource management practices and procedures from the position of an HR leader of a new generation hospital in Slovakia. The research findings and discussion are enriched with her own empirical knowledge about the practical human resource management in the context of inpatient healthcare.

\section{Research results and discussion}

Based on an examination of the findings of published studies, we find a demonstrated link between the sophistication of human resource management systems and medical performance. The subject of the research published in the article was the current challenges for human resource management in healthcare in the Slovak Republic and the readiness of medical personnel with managerial competence to manage people. Examples of good practice of developed human resource management from world hospitals were part of the research.

\subsection{The challenges of human resource management in healthcare}

In order to define the main challenges facing human resource management in the Slovak healthcare system, it is important to know the broader context and development trends. A major influence is the persistent shortage of health workers in Slovakia. In 2019, the Health 
Policy Institute found from statistical collection that there is a shortage of 2,900 doctors and 3,600 nurses [14].

In 2030, the Institute predicts that this will be nearly ten thousand nurses [14]. The 2017 census of doctors in Slovakia showed that there are more than four thousand doctors from Slovakia abroad, most of them in the Czech Republic, according to Haníková and Koník [18]. The shortage of doctors and nurses worries more than $82 \%$ of Slovak hospital directors involved in the HealthCare Institute's Healthcare Barometer 2020 survey, a nonprofit organization focused on improving the quality of healthcare provided in hospitals [19]. As a consequence of staff shortages, the problem of overtime work of doctors and nurses is growing. More than half of hospital directors consider this to be a problem for physicians, and as many as two-thirds of directors consider it to be a problem for nurses [19]. Staff shortages also have a negative impact on the training of young doctors in clinics. In a state where there is a shortage of staff in the wards, doctors do not have time for med students [18]. Teaching others is seen, as a burden and does not support the transition to a learning organization in the future. Another management challenge in the health sector is relatively low competitiveness of remuneration, which results in health workers going abroad (doctors and nurses) or to other sectors where they receive higher pay for equally demanding work (especially nurses).

The historically stable healthcare environment has changed significantly over the last two decades, with an outflow of workers abroad and a decline in interest in the healthcare profession in general. Unaware of the seriousness of the situation, the HRM units have reacted to the changes in the environment mainly in a transactional manner. For example, they compensated for staff shortages by increasing financial compensation and benefits, often at the expense of deepening the organization's losses [17]. From author's own empirical experience, we conclude that transformational tools of higher levels of HRM, such as defining the employer value proposition (EVP) for the employee, talent management, and the development of leadership skills of managers, can be observed only in their infancy so far.

At present, modern HRM tools are used in the healthcare sector in a limited way - often only at the level of wages and personnel administration, labour law and union bargaining. This indicates a low level of HR development $[9,10]$.

Empirical evidence shows that in Slovakia we can observe significant differences in the development of HR departments also between state, Slovak and foreign organizations. More often we find developed HR departments especially in organizations with highly competitive pressure and in foreign organizations that bring good practices from their parent headquarters. Furthermore, the possibility of specialisation of individual HRM staff increases with the size of the organisation and this allows for an increase in the quality of HRM processes.

For a long period of time, the Slovak health sector was a stable environment with absolute predominance of state ownership, while in the field of inpatient healthcare, individual hospitals belonged in size to medium-sized organisations with a regional monopoly. These characteristics did not create an environment in which there was pressure to develop the quality of HRM and, compared to other organisations (especially foreign ones in a highly competitive segment), therefore, human resource management in institutional healthcare facilities lagged behind.

The main role of the HR department in hospitals is usually recruitment, provision of mandatory statutory training and payroll. It is often part of the finance or legal department. This empirical evidence shows that in most hospitals in Slovakia the HRM department is at the first or second development level.

The fact that Slovak hospitals are generally not using developed HR processes nor are participating in the management of corporate culture is documented in the article by Raijani 
et al. [20], in which they describe in detail the managerial processes in Slovak hospitals, but with only a marginal mention of the current active role of human resource management. This view is confirmed by the results of the Healthcare Barometer survey, according to which the most popular measure to ensure sufficient staffing is benefits such as company meals and extra holidays for up to $91 \%$ of Slovak hospital directors [19]. However, these tools are transactional and do not address the causes of disinterest in the healthcare profession and a given hospital.

When interviewing health workers, we repeatedly encounter information that selections are not transparent, recruiters do not respond to CVs sent, adaptation of new employees is unmanaged and the management skills of supervisors are weak. Similar experiences are communicated by the media from time to time [18].

Low level of managerial skills has been also observed by author during selection procedures for managerial positions in nursing for the New Generation Hospital Bory. Candidates usually had excellent professional knowledge and skills, but their management style was predominantly directive, coupled with low self-awareness of its impact on the teams being managed. In doing so, Jankel and Joniakova [13] state that it is the management skills, especially the managerial style of the leader, that have a significant impact on employee satisfaction and motivation. They point out that organizational support (e.g., including HRM systems) has been identified as a predictor of employee satisfaction and manager empowerment. Alshamari emphasizes that organizational culture plays a significant role in enhancing organizational performance [14]. Several authors emphasize that an organization needs a well-developed HRM system to enable managers to be effective. Leadership can only be as good as the infrastructure that supports it [13, 21].

\subsection{Readiness of managers to manage people in the health sector in the SR}

Nowadays, the best medical experts often become managers in Slovak medical institutions. When they take up the position, they often have only basic managerial knowledge and learn the management of the entrusted department on the fly [22]. These first-line managers (senior physicians, station nurses, day shift managers) later move up the career ladder to middle management (chief physicians, head nurses) and up to hospital management (deputy medical-preventive service, deputy for nursing, hospital director).

Management and human resource management in the Slovak healthcare sector is not a prerequisite for all positions (e.g., for nurses, a minimum of 15 years of experience is sufficient). It is taught only marginally ( 1 semester) in undergraduate medical studies and includes the basics of healthcare management and leadership. Theoretical knowledge is not supported by practice in the workplace [23].

HRM is also taught within the management specialties that are the basis for the medical management position. HRM is usually only a small part of the content, which is surprisingly low for a sector with a high proportion of value added by human labour. The content presented is second level HRM, i.e., strategic HRM with a strong emphasis on selection, recruitment and training of staff and, from the organisational area, on the motivational skills of managers.

The question remains of translating what has been learned from the human resource management field into practice. According to research by Wild and Fulopova [24], graduates of the MPH program subjectively rated their theoretical knowledge and practical skills on average at the very good level. On the basis of more than 400 interviews completed with healthcare professionals over the last 2.5 years, we can conclude that the above knowledge often remains at the level of knowledge and is not translated into behaviour change of healthcare managers or into HRM processes. 
Alongside the still prevailing model of the manager-expert (doctor, nurse, etc.), an independent role of the professional manager in healthcare has emerged in the Western Europe. These are managers who have graduated in healthcare management (MPH, MSc., MHA, or others) and their role in the healthcare facility is not medical, but managerial. The staffing of management professionals into senior healthcare positions is seen in countries such as the UK, Spain, and Germany, where the decentralization of healthcare has increased the need for management skills at the highest levels of healthcare facilities [22]. In Slovakia, a similar trend is gradually occurring - professional managers without a medical background take leading roles in hospitals (e.g., Ing. Miriam Lapuníková, MBA Director of FNSP F.D. Roosevelt Banská Bystrica, or Ing. Marián Haviernik - Director of the New Generation Hospital Michalovce).

\subsection{Advanced human resource management in hospitals - examples of good practice}

HRM in the healthcare segment of the economy is not usually among the best the world of HR has to offer. According to Lüthy [25], there is still a negative attitude among hospitals towards trying to be an attractive employer. Hospital management often believes that working in a hospital is fundamentally very difficult and there is not much that can be done about it. However, according to Lüthy [25] this is not the right approach and suggests measures to improve the situation: professional leadership, motivation and rewarding of coworkers, further education and career planning, optimization of processes and avoiding bureaucratization, flexible working arrangements, work-family balance, and the formulation of codes of ethics to deal with internal and external stakeholders. For example, a study from Germany concludes that a hospital is not an attractive workplace, but can become one if it improves in particular personal development opportunities and the work life balance [26].

Below we give examples of good practice, of some hospitals that are successful in ensuring the above and their HRM departments are in the third to fourth developmental level of human resource management.

The Mayo Clinic network of hospitals is one of the best healthcare facilities in the United States. Their leadership and corporate culture rating are A to A+, according to Comparably.com, a site comparing multiple US employers over the long term [27]. HRM at Mayo Clinic supports the organization's strategy and measures the impact of HRM activities and policies on its performance, which is typical of fourth level of HRM. Mayo Clinic has continuous professional learning in its organizational DNA, but also strong support for diversity and adherence to the organization's values, with teamwork as a core value.

The largest private hospital network in Germany is Helios. Employing over 66,000 employees in 86 clinics throughout Germany and treating over 5.2 million patients annually, it addresses the topic of human resource management and productivity long term and professionally. According to Bornewasser et al. Helios managers point to several areas that enable high employee motivation and the associated continuous improvement of the productivity of their clinics [28]. High labour productivity brings the network long-term growing revenues, which are further invested in increasing healthcare delivery. The main employer levers at Helios include education, career opportunities, work-family balance and healthcare.

An example of a high level of HRM is the British NHS (National Health Service). The NHS is the largest public healthcare provider in the UK and the second largest public healthcare provider in the world (after Brazil). The NHS presents its human resource management to a high standard. It has elaborated in detail the different HR specialties 
(selection, training, remuneration, ...) and presents them openly externally through its web portal [29]. It makes significant use of elements of the third and fourth development levels of HR. A clear HR strategy is publicly communicated and accessible to all employees on the intranet and to job applicants and the public on the external web. For example, the employer's employee value proposition - description of what it is like to work for the organization - is communicated through the "People Promise" video. In it, individual employees talk about their experience in the NHS, communicating the culture of the organisation and how they work within it. The NHS actively responds to societal challenges and encourages new ways of working (flexible working for all roles, working remotely via technology - e.g., through video consultations with a doctor), new innovative roles (e.g., involving scientists in the treatment process), acquiring new skills (generalist skills from other areas) and learning through technology (a significant part of learning available 24/7 online). In the area of management and leadership, organization emphases the need for inclusive situational leadership, taking into account the diversity of the workforce and creating space for employee empowerment. It relies heavily on data collection, data analysis and modelling of future scenarios [30].

\section{Conclusion}

Based on current knowledge about human resource management in the healthcare, we find a proven relationship between developed human resource management and healthcare quality. Research findings highlight the need for a focused improving the functioning of relevant HRM systems in healthcare as one of the factors for improving patient care [10]. The quality of healthcare and the level of medical performance in Slovakia have long been undermined by a shortage of healthcare personnel and the poor readiness of health care managers to manage people. Research findings suggest that the key challenge of human resource management systems in healthcare in the Slovak Republic is attraction and retention. The way to build the attractiveness of the health profession and eliminate the departure of Slovak health professionals abroad is quality human resource management in its mature stage of development. Furthermore, defining and communicating the value of the employee experience of working in healthcare is important. According to Jankelova [9], it is leaders who play a key role in creating the organizational conditions in which a developed HRM system can be implemented. Here we see the role of management education of healthcare employees, which does not remain only at the level of the University curriculum, but continues further on the job. We see the quality of human resource management in hospitals as the foundation of quality healthcare.

\section{Aknowledgement}

Supported by the Scientific Grant Agency of the Ministry of Education of Slovak Republic and the Slovak Academy of Sciences VEGA Project No. 1/0412/19 Systems of Human Resources Management in 4.0 Industry Era.

\section{References}

1. V. Ozorovský, I. Vojteková a kolektív, Zdravotnícky manažment a financovanie, Wolters Kluwer, 2016, 168-178, (2016) ISBN 978-80-8168-522-4 
2. Európska Komisia, Biela kniha o budúcnosti Európy - Úvahy a scenáre pre štáty EÚ27 k vývoju do roku 2025, Európska komisia, 2017, (1. 3.2017) ISBN: 978-92-7967631-4, DOI:10.2775/88238

3. P. Hroboň, Changing forms of care needed to ensure accessibility and quality - lecture during Prague International Health Summit, intern document of Svet Zdravia - online conference recording, 1.-2.10.2020 (2020)

4. W. Quentin, Transformation of national hospital networks - lecture during Prague International Health Summit, intern document of Svet Zdravia - online conference recording, 1.-2.10.2020 (2020)

5. J. Bersin, Talent Strategies in Asia: Do Asian Leaders Behave Differently?, HR Management App, (2019) visited 16.1.2021 on https://www.hrmanagementapp.com/ talent-strategies-in-asia-do-asian-leaders-behave-differently/

6. E. Volini et al, The social Enterprise at work: paradox as path forward - 2020, Deloitte Global Human Capital trends, (2020)

7. D. Ulrich, Majrstrovské řízení lidských zdrojú, Grada, 29 (2009) ISBN 978-80-2473058-5

8. J. Blštáková, Habilitation lecture - Readiness of Slovak enterprises to manage the new generation of employees in the conditions of Industry 4.0, FPH EUBA, 4-5 (2018)

9. N. Jankelova, The Key role of Strategically and People - oriented HRM in Hospitals in Slovakia in the Context of Their Organizational Performance, Healthcare, Vol 9, Iss 255, 31-33 (2021)

10. M. West, J. Guthrie, J.Dawson, C.Borrill, M. Carter, Reducing patient mortality in hospitals: The role of Human Resource Management, Journal of Organizational Behaviour 27, 983-1002 (2006)

11. K. Townsend, A. Wilkinson, C. Allan, G. Bamber, All we need is a miracle: Using a solution-based approach to human resource management in hospitals, Asia Pacific Journal of Human Resources, 49 (2), 177 (2011) DOI: 10.1177/1038411111400163

12. K. Townsend, A. Wilkinson, C. Allan, Mixed signals in HRM: the HRM role of hospital line managers, Human Resource Management Journal, Vol 22, no 3, 267-282 (2012)

13. N. Jankelová, Z. Joniaková, Communication Skills and Transformational Leadership Style of First-Line Nurse Managers in Relation to Job Satisfaction of Nurses and Moderators of This Relationship. Healthcare, 2021, 9, 346 (2021) https:// doi.org/10.3390/healthcare9030346

14. S. Alshamari, Organizational Culture and Organizational Performance in the Primary Health Care Sector in Qatar: A proposed Theoretical Framework, Cross-Cultural Management Journal, Volume XIX, Issue 2/2017, 130 - 136 (2017)

15. K. Alfes, A. Shantz, C. Truss, E. Soane, The link between perceived HRM practices, engagement and employee behaviour: a moderated mediation model, International Journal of Human Resource Management, Vol 24 , no. 2 , 330-351 (2013) DOI:10.1080/09585192.2012.679950

16. A Baluch, T. Salge, E. Piening, Untangling the relationship between HRM and hospital performance: The mediating role of attitudinal and behavioral HR outcomes International Journal of Human Resource Management, September 2013, 24(16) 3038-3061 (2013) DOI: 10.1080/09585192.2013.775027

17. Value for Money Unit Ministry of Finance of the Slovak Republic, Health Expenditure Review II - Final Report, October 2019, 11 (2019) https://www.mfsr.sk/files/archiv/44/revizia zdravotnictvo_2.pdf

18. L. Haniková, J. Koník, A young doctor went to the Czech Republic, here she was asked in interviews when she wanted to have children and what the parents were doing, Dennik N, 19.10.2020, (2020) 
19. Healthcare Institute, Healthcare Barometer - survey of Czech and Slovak healthcare directors, HCI, 2020, 5 (2020)

20. I. Raijani, R. Bačík, R. Fedorko, M. Rigeslký, K. Szczepanska-Wosyczyna, The alternative model for quality evaluation of health care facilities based on outputs of management processes, Polish Journal of Management Studies, 17(1), 194-208 (2018), DOI: 10.17512/pjms.2018.17.1.16

21. M. Bender, Conceptualizing Clinical Nurse Leader Practice: An Interpretive Synthesis, J. Nurs. Manager, 23-31, (2016)

22. T. Hudák, V. Šušňáková, Manažérske vzdelávanie zdravotníckych pracovníkov v Európe a USA, Katolícka univerzita v Ružomberku, Pedagogická fakulta, Katedra manažmentu, I180, visited 15.1.2021 on https://www.tvp.zcu.cz/cd/2014/PDF_sbornik/ hudak\%20susnakova.pdf

23. P. Ondruš, I. Ondrušová a spol., Manažment a financovanie v zdravotníctve - príručka zdravotníckeho manažéra, Matica slovenská, 9-19 (2017), ISBN 978-80-972535-9-2

24. K. Wild, A. Fulupova, Hodnotenie manažérskeho vzdelávania v odbore odborník na riadenie vo verejnom zdravotníctve - Master of Public Health (MPH), Verejné zdravotníctvo (online), ročník VII č.1, (2010) ISSN 1337-1789, visited 15.1.2021 on www.verejnezdravotnictvo.sk

25. A. Lüthy, Mitarbeiterorientierte Personalpolitik: Wie Krankenhäuser attraktive Arbeitgeber werden, Krankenhausmanagement : Strategien, Konzepte, Methoden, Berlin : MWV Medizinisch Wissenschaftl. Verl.-Ges.,133-141 (2010) ISBN 978-3941468-26-9

26. J. Hunák, Master thesis: From public to private: effects of hospital privatization on the work environment of physicians - a case from Slovakia, Wirtschaftsuniversität Wien, 17-20 (2018)

27. UKESSAYS, Strategic HRM at the Mayo Clinic business essay, November 2018, visited 15.1.2021 on https://www.ukessays.com/essays/business/strategic-hrm-at-themayo-clinic-business-essay.php?vref=1

28. M. Bornewasser, B. Kriegesman, J. Zuelch, Dienstleistungen in Gesundheitssektor Produktivität, Arbeit und Management, Springer Gabler, (2014) ISBN 978-3-65802957-9

29. NHS, Workforce plan, 2020, visited 15.1.2021 on https://www.nhsemployers.org/yourworkforce/plan/medical-workforce/new-to-managing-doctors-a-guide-for-hrpractitioners)

30. NHS, We are the NHS - action for all of us, 2020, visited 15.1.2021 on https://www.england.nhs.uk/wpcontent/uploads/2020/07/We_Are_The_NHS_Action_ For_All_Of_Us_FINAL_24_08_20.pdf 